\title{
THE EFFECT OF FAMILIAL BALANCED RECIPROCAL TRANLOCATION t(9;11)(p12;p11.2) TO REPRODUCTIVE PERFORMANCE
}

\author{
Gulsen OKTEN $^{1}$, Nurten KARA ${ }^{1}$, Sengul TURAL ${ }^{1}$, Davut GUVEN ${ }^{2}$, Nevin KARAKUS ${ }^{1}$ \\ ${ }^{1}$ Department of Medical Biology and Medical Genetics, Ondokuz Mayis University, Faculty of Medicine, Samsun, Turkey \\ 2 Department of Gynecology and Obstetric, Ondokuz Mayis University, Faculty of Medicine, Samsun, Turkey
}

\section{SUMMARY}

\begin{abstract}
Aim: In this study, we report a couple who had been infertility problem for eight years and they had four failed IUI and one failed IVF. In second IVF attempt the women got pregnant and it resulted with abortion in eight week. Material and metods: Cytogenetic analysis was performed by standart peripheral blood culture and GTG method by using phytohemagglutinin-stimulated lymphocyte.

Results: The women and her husband were phenotypically normal but karyotype analysis revealed 46, XX and $46, X Y, t(9 ; 11)(p 12 ; p 11.2)$ respectively. The mother of the husband's karyotype analysis showed the same translocation. The father of the husband's could not examined because he was not alive. Also two uncles of the husband were suffered from infertility for fifteen and five years respectively. However cytogenetic analyses of the uncles had not been accomplished yet. Balanced translocation carriers could give unbalanced chromosomes.

Conclusion: The infertility cases of especially monosomy $9 p$ and the other similar translocations that can result from the parents of balanced translocation carriers are represented here by comparing.
\end{abstract}

Key words: chromosomal translocation, infertility

Journal of Turkish Society of Obstetrics and Gynecology, (J Turk Soc Obstet Gynecol), 2012; Vol: 9, Issue: 3, Pages: 173- 6

\section{AİLESEL DENGELİ RESIPROKAL TRANSLOKASYON t(9;11)(p12;p11.2)'UN ÜREME PERFORMANSINA ETKISI}

\section{ÖZET}

Amaç: Bu çalışmada, sekiz yıldır infertil, dört IUI (Intrauterin Inseminasyon) denemesinin başarısız, IVF (In Vitro Fertilizasyon) denemesinin ikincisinde başarll olan fakat 8 haftallkken gebelik kaybu yaşayan bir çift sunuldu. Gereç ve yöntemler: Sitogenetik analizde, periferik kandan elde edilen kromozomlara tripsin gimza bantlama (GTG) uygulanarak karyotip analizleri yapuldl.

Bulgular: Fenotipik olarak normal görülen olgularin karyotipleri 46,XX ve 46,XY,t(9;11)(p12;p11.2) olarak saptandl. Erkek olgunun annesinde de aynı translokasyon bulundu. Baba hayatta olmadığından incelenemedi. Ayrıca olgunun iki daylsinın oğullarından biri 15 yıllık evli ve infertil, diğeri 5 ylldır evli ve infertildir, bu kişsilere henüz ulaşılamadiğından incelenemedi. Tartışma: Dengeli translokasyonlu olgumuzun verebileceği gametlerden özellikle 9p monozomisi ve infertilitenin birlikte görüldüğ̈̈ diğer benzer translokasyonlu olgular karşılașttrılarak sunulmuştur.

Anahtar kelimeler: kromozomal translokasyon, infertilite

Türk Jinekoloji ve Obstetrik Derneği Dergisi, (J Turk Soc Obstet Gynecol), 2012; Cilt: 9, Sayl: 3, Sayfa: $173-6$

Address for Correspondence: Dr. Gülsen Ökten. Ondokuz Mayıs Üniversitesi Tıp Fakültesi, Tıbbi Biyoloji Anabilim Dalı, 55139 Samsun, Turkey Phone: + 90 (533) 4925282

e-mail: stural@omu.edu.tr

Received: 04 August 2011, revised: 30 November 2011, accepted: 11 January 2012, online publication: 12 January 2012 


\section{INTRODUCTION}

Several studies have been shown that, aneuploidy, translocations, inversions, deletions of the $\mathrm{Y}$ chromosome and DNA damage may be effective in infertility(1). Chromosomal anomaly frequencies reported in the general population are lower than $1 \%$, whereas patients with reproductive problems groups in around 5\%. Among these changes, autosomal Robertsonian translocations and chromosome aberrations are ranks first in ${ }^{(2)}$. Chromosomal anomalies are more common in infertile men although the cause of infertility in both men and women can $^{(3)}$. Especially in infertile male patients, incidence of somatic chromosomal abnormalities have been reported between $2.2 \%$ and 19.6. Sex chromosome abnormalities are the most common in human chromosomal abnormalities. The rate of sex chromosome abnormality in infertile men is $3.8 \%$, while the abnormality rate of autosomal chromosomes are $1.3 \%{ }^{(4)}$. When infertile males compared to those of normal, the incidence of structural chromosomal abnormalities in men 1-4 times higher ${ }^{(1-5)}$. These anomalies influence the reproduction. If the number of sperm reduces, incidance of anomaly increases. In oligospermia group, the most common anomilies are autosomal anomalies (3\%), while in azoospermia group sex chromosome abnormalities $(12.6 \%)$ are dominant ${ }^{(6)}$. Changes in autosomal chromosomes, especially in Robertson-type translocations, during spermatogenesis may disturb some central effects of sperm density. Similar anomalies in the female carriers gametogenesis appears, however, is not affected. Therefore, in female carriers there is a risk of having spontaneous abortion or malformed children. However, male carriers of chromosomal abnormalities may cause sterility or subfertility $(7)$. In this study, a family carrier of chromosomal $t(9,11)(p 12: p 11.2)$ with reproductive problems were presented.

\section{CASE REPORT}

Informed consent was taken all from family members and conventional cytogenetic methods and GTG (Giemsa-Trypsin) banding techniques were applied. Chromosome analysis were done, 30 metaphases were examined and 10 metaphases were karyotyped. Karyotypes were described according to the International System for Cytogenetic Nomenclature 2009(8). We presented a couple who have been suffered from infertiliy for eight years. After 4 failed IUI (IntrauterinInseminasyon), the second IVF (In Vitro Fertilizasyon) was succesfull but it resulted 8 weeks of pregnancy loss. The couple karyotype results were $46, \mathrm{XX}$ and 46,XY, t(9;11)(p12;p11.2). In family examination, mother of the male case who has the same translocation, could got pregnant after three years and fist one was stillbirth and second one was first trimester pregnancy loss. After these, she had got a healty child (Generation III, individual 11). Father of male case could not examined because he is not survive. Also generation III individual 2 married for 15 years and generation III individual 6 married for 5 years were also suffer from infertiliy but we could not reached them and we could not examine their karyotypes (Figure 2).

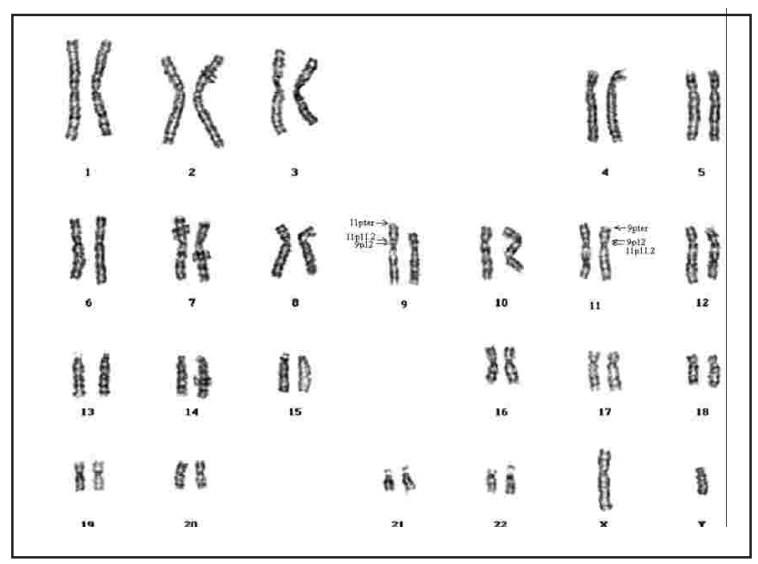

Table 1: Karyotype of the case.

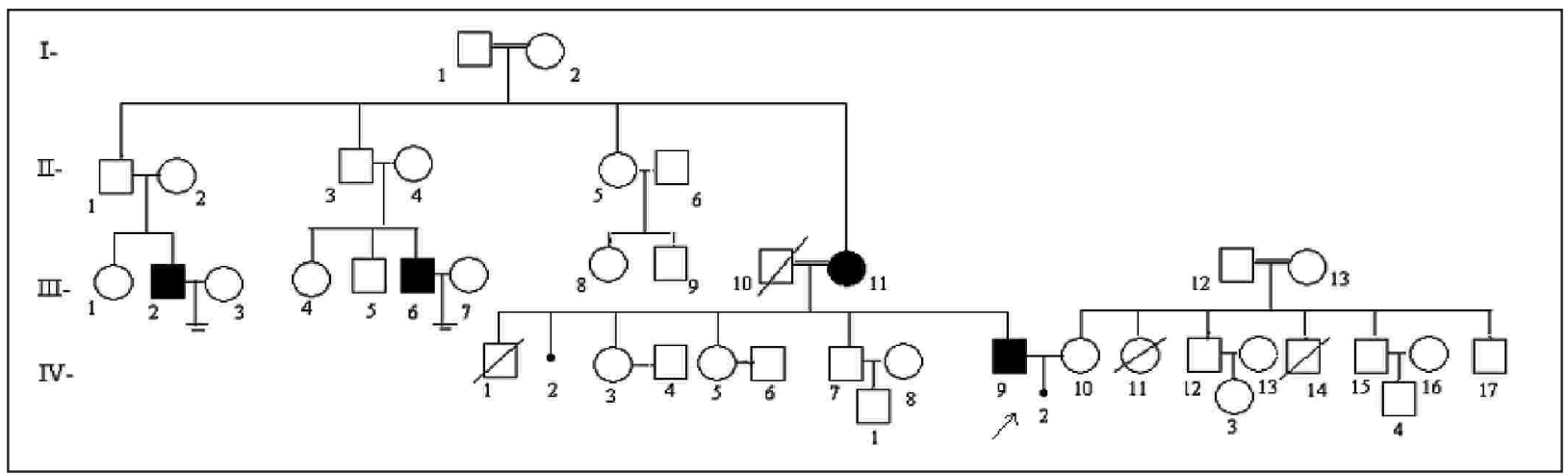

Table 2: Pedigre of the family. 


\section{DISCUSSION}

Translocations are more common in infertile males than normal males ${ }^{(9)}$. These kinds of chromosomal rearrangements cause formation of unbalanced gametes by negatively affecting the spermatogenesis. These unbalanced gametes may cause disorders like recurrent pregnancy lose, congenital malformation, delayed development and mental retardation.

In a 46,XX,t $(9 ; 11)(\mathrm{p} 22 ; \mathrm{p} 15.5)$ case with different breakpoints from our case, the $S R Y$ gene was assigned to be positive, and delayed development and sex reversal were also observed ${ }^{(10)}$. Further, an infertile case with a 46,XY,t(9;15)(p10;q10) karyotype was defined(11). Gonadal disgenesis and sex reversal (phenotypically male) were also observed in a case with $9 \mathrm{p}$ monosomy. Cases of infertility and sex reversal with different translocations of chromosome 9 were reported; $t(9 ; 13)$, $\mathrm{t}(9 ; 3), \mathrm{t}(7 ; 9), \mathrm{t}(2 ; 9), \mathrm{t}(4 ; 9), \mathrm{del} 9(\mathrm{p} 23)^{(12-17)}$. In various leukemia patients, $\mathrm{t}(9 ; 11)$ cases with different break points were observed $(18,19)$. Infertility cases with balanced translocations of different chromosomes were also reported $(4,6,11,20)$. The common results of these findings were the possible association of chromosomal abnormalities with incorrect chromosome coupling and crossing over in meiosis. The other possibility is the prohibition of the genes, related to testicular development and function, in chromosomal break points. The translocation in our case did not influence spermatogenesis, because the result of spermiogram test was normal. TET1 (testis-expressed transcript) gene was mapped in the 9p21-22 band region which was in the break point of our case ${ }^{(6)}$. The translocation of TET1 to chromosome 11 might cause infertility by showing a different position effect. As a result, in the translocated region, a detailed molecular analysis is needed to be done because of the possible cause of this region to infertility, especially in males.

\section{Conclusion}

In this study, it was emphasized that, chromosomal translocations might have an important role in the etiology of infertility and a detailed molecular analyses of genes, inside the related break points, had to be done.

\section{KAYNAKLAR}

1. Ioannou, D. ve Griffin, D.K. Male Fertility, Chromosome Abnormalities, and Nuclear Organization. Cytogenet Genome Res 2011; 133: 269- 79 .

2. Pernice, F., Mazza, G., Puglisi, D., Luppino, M.G., Frisina, N. Nonrobertsonian translocation $\mathrm{t}(6 ; 11)$ is associated with infertility in an oligoazoospermic male. Fertil Steril. 2002; 78: $192-4$.

3. Healy, D.L. Female infertility: Causes and treatment. The Lancet. 1994; 18: 343(8912): 1539- 44.

4. Goel, H. \& Phadke S. R. Reciprocal balanced translocation: infertility and recurrent spontaneous abortions in a family. Andrologia 2009; 43, 75- 7.

5. O'Flynn O'Brien K.L, Varghese, A.C., Agarwal, A. The genetic causes of male factor infertility:a review. Fertil Steril 2010; 93: $1-12$

6. Erol D. ve Yüce H. Oligospermik İnfertil Bir Erkekte Resiprokal Translokasyon t(1;5)(p33;qter). Firat Tip Dergisi 2009; 14(3): 204- 6

7. Badovinac, A.R., Tomljanovic, A.B., Stracevic, N. et all. Chromosome studies in patiens with defective reproductive success, AJRI. 2000; 44: 279- 83.

8. Shaffer L.G, Slovak M.L., Campbell L.J. ISCN 2009: An International System for Human Cytogenetic Nomenclature (2009): Recommendations of the International Standing Committee on Human Cytogenetic Nomenclature, 2009; S. Karger, Basel.

9. Van Assche, E., Bonduelle, M., Tournaye, H. et al. Cytogenetics of infertile men. Hum Reprod. 1996;11 Suppl 4: 1- 24.

10. Prabhakara, K., Angalena, R., Ramadevi, A.R. Familial $(9 ; 11)$ (p22;p15.5)pat translocation and XX sex reversal in a phenotypic boy with cryptorchidism and delayed development. Genet Couns. 2004; 15(1), 37- 41

11. Aydos, S. A., and Tükün, A. Infertility in a man with oligoasthenoteratozoospermia associated with nonrobertsonian translocation $\mathrm{t}(9 ; 15)(\mathrm{p} 10 ; \mathrm{q} 10)$. Fertil and Steril 2006; 86(4): $1001 \mathrm{e} 7-1001 \mathrm{e} 8$.

12. Jotterand, M., Juillard, E. A new case of trisomy for the distal part of $13 \mathrm{q}$ due to maternal translocation $\mathrm{t}(9 ; 13)(\mathrm{p} 21 ; \mathrm{q} 21)$. Hum Genet. 1976;33: 213- 22

13. Fryns, J.P., Kleczkowska, A., Casaer, P. Van den Berghe, H. Double autosomal chromosomal aberration ( $3 p$ trisomy $/ 9 p$ monosomy) and sexreversal. Ann Gnt 1986; 29: 49- 52.

14. Crocker, M., Coghill, S.B., Cortinho, R. An unbalanced autosomal translocation $(7 ; 9)$ associated with feminization. Clin Genet. 1988; 34: 70- 3

15. Hoo, J.J., Salafsky, I.S., Lin, C.C. Possible localisation of a 
recessive testis forming gene on 9p24. Am J Hum Genet (Suppl). 1989;45: A78

16. Bennett, C.P., Docherty, Z., Robb, S.A., Ramani, P., Hawkins, J.R., Grant, D. Deletion 9p and sex reversal. J Med Genet 1993; 30: 518- 20.

17. Marie, T., McDonald, W. F., Sheldon, S., Putzi, M.J. and Gorski, J. L. XY Sex Reversal and Gonadal Dysgenesis Due to 9p24 Monosomy American Journal of Medical Genetics 1997; 73: 321- 6

18. Chandra P., Luthra R., Zuo Z., Hui Yao, Ravandi F., Reddy N, Garcia-Manero G., Kantarjian H., and Jones D., Acute Myeloid Leukemia With t(9;11)(p21-22;q23) Common
Properties of Dysregulated Ras Pathway Signaling and Genomic Progression Characterize De Novo and TherapyRelated Cases. Am J Clin Pathol 2010; 133: 686- 93 DOI: 10.1309/AJCPGII1TT4NYOGI.

19. Belli, C. Alú, M.F. Alfonso, G. Bianchini, M. Larripa, I. Novel Variant Ph Translocation $\mathrm{t}(9 ; 22 ; 11)(\mathrm{q} 34 ; \mathrm{q} 11.2 ; \mathrm{p} 15)$ $\operatorname{inv}(9)(\mathrm{p} 13 \mathrm{q} 34)$ in ChronicLeukemia Involving a One-Step Mechanisma Cytogenet Genome Res 2011; 132: 304-8. DOI: $10.1159 / 000322824$.

20. Venkateshwari, A., Srilekha, A., Begum, A., Sujatha, M., Sunitha, T. et al.. De novo chromosomal translocation $\mathrm{t}(3 ; 5)$ (q13;q35) in an infertile man. Andrologia 2010; 43, 428- 30. 